\title{
Immuno-Fluorescent Reactivity to Anti-Somatostatin in the Gastro-Intestinal Mucosa of the Dog
}

\author{
C. Rufener, M.P. Dubois, F. Malaisse-Lagae and L. Orci \\ Institut d'Histologie et d'Embryologie, Ecole de Médecine, Genève, Suisse and I.N.R.A., Station de Physiologie de la Reproduction, \\ Nouzilly, France
}

Received: May 17, 1975, and in revised form: May 23, 1975

\begin{abstract}
Summary. Evidence is presented that somatostatin-containing cells are present in the gastro-intestinal tract of the dog. Thus immuno-fluorescent cells were detected by the use of antiserum to cyclic somatostatin. These cells were mainly encountered in the antral mucosa and in the neighbourhood of gastrin-producing cells. No cross reaction was observed between gastrin and somatostatin. It is suggested that locally produced somatostatin controls gastrin
\end{abstract}

secretion, and, more generally, that somatostatin-containing cells, multifocally distributed, modulates secretion of a large number of glands.

Key words: Immuno-fluorescence, gastro-intestinal tract, somatostatin, gastrin.
Somatostatin, a growth hormone release-inhibiting factor (or GIF) has been isolated from the hypothalamus [1]. In addition to its action on growth hormone release, somatostatin has been demonstrated to inhibit the release of insulin, glucagon, gut glucagon, thyroid stimulating hormone and gastrin [2-16]. Antibodies to somatostatin allowed immunohistochemical studies in the hypothalamus [17-19] and the endocrine pancreas $[20,21]$. We reporthere the presence of immunohistochemically positive cells to anti-somatostatin serum in the gastro-intestinal tract of the dog ${ }^{1}$.

\section{Material and Methods}

\section{Tissue Preparation}

The different portions of the GI tract of dogs were fixed in Bouin's solution (2.2\% picric acid, $10 \%$ formaldehyde and $5 \%$ acetic acid), dehydrated, and embedded in paraffin. Five microns thick sections were mounted on albumin-covered slides, rehydrated after removal of paraffin and processed for immunohistochemistry.

\section{Antisera}

Cyclic somatostatin was conjugated to human serum albumin by means of glutaraldehyde or diamino-benzidin and emulsified in Freund's com-

\footnotetext{
${ }^{1}$ While this manuscript was in preparation, Arimura and coworkers have reported on the presence of somatostatin in high concentrations in gastric and pancreatic extracts of the rat [22].
}

plete adjuvant [19]. Rabbits were immunized by the injection of $1100 \mu \mathrm{g}$ of somatostin per animal, divided in three doses administered at three weeks intervals [21]. For immuno-fluorescence the antiserum was diluted $1: 200$ in phosphate buffered saline (PBS). Antibodies to synthetic human gastrin I (SHG 2-17, Imperial Chemical Ind. Ltd) raised in rabbits were a generous gift from Dr. W. Gepts (Vrije Universiteit, Brussels, Belgium) [23]. Fluorescein isothiocyanate (FITC) conjugated to sheep antirabbit immunoglobulin was obtained commercially (Pasteur Institute, Paris).

\section{Controls}

The following controls were used:

a) anti-somatostatin serum mixed with an excess of synthetic somatostatin $(200 \mu \mathrm{g} / \mathrm{ml})$.

b) anti-somatostatin serum mixed with an excess of synthetic gastrin $(50 \mu \mathrm{g} / \mathrm{ml})$.

c) anti-gastrin serum mixed with an excess of synthetic gastrin $(50 \mu \mathrm{g} / \mathrm{ml})$.

d) anti-gastrin serum mixed with an excess of synthetic somatostatin $(200 \mu \mathrm{g} / \mathrm{ml})$.

e) normal rabbit serum.

f) FITC alone.

\section{Immuno-Fluorescence}

The indirect immuno-fluorescence technique was applied [24]. Sections were incubated with the first antiserum (anti-somatostatin, anti-gastrin or the con- 

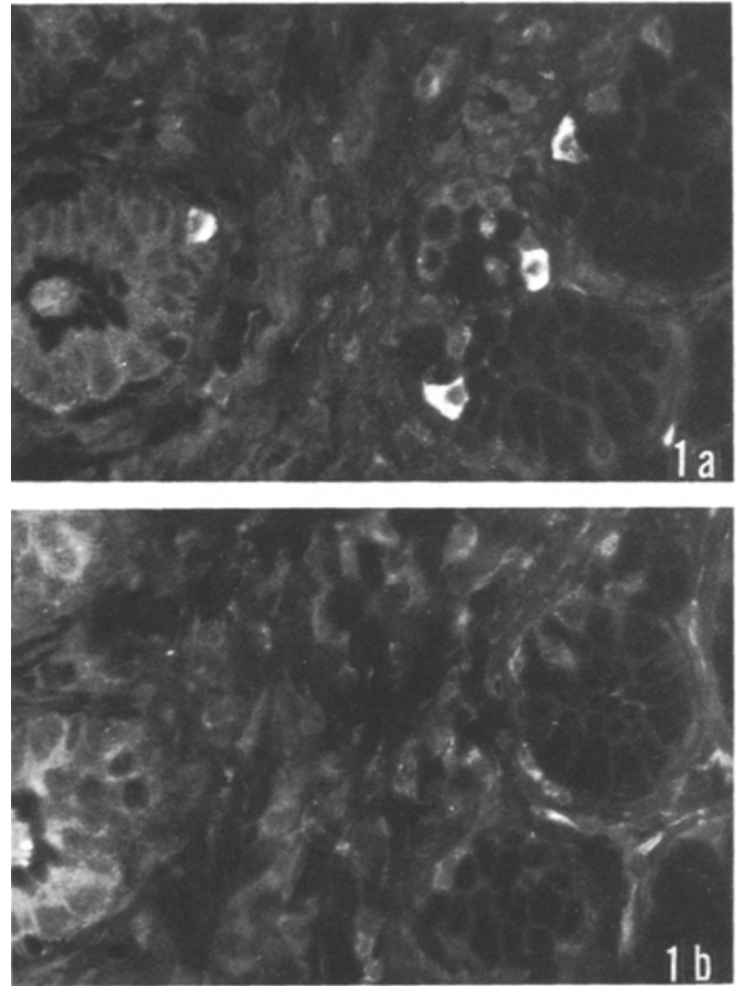

Fig. 1. Two serial sections from dog antral mucosa. a) Incubation with anti-somatostatin serum. Four fluorescent cells are seen in the glands. b) Incubation with anti-somatostatin serum adsorbed with an excess of synthetic somatostatin (control a). Fluorescence is completely abolished in the cells $\times 400$

trols) at room temperature for one hour, rinsed with PBS, incubated with FITC for one hour, rinsed again with PBS, counterstained with Evans'Blue $(0.01 \%)$ for $5 \mathrm{~min}$, and mounted in glycerin-PBS. The sections were observed in a Zeiss Ultraphot microscope equipped with a III RS condenser.

\section{Results}

After incubation with anti-somatostatin serum, immuno-fluorescent cells were found along the entire gastro-intestinal tract. They were particularly abundant, however, in the antral mucosa, in the neighbourhood of gastrin-producing cells (Fig. 1a). In view of the prevalence of somatostatin-containing cells in regions which are also abundant in gastrinproducing cells, we tested the sections for a possible cross-reaction between gastrin and somatostatin. The anti-somatostatin immuno-fluorescence was eliminated by prior incubation of the serum with synthetic somatostatin (control a; Fig. 1b), but was not suppressed by mixing the anti-somatostatin serum with
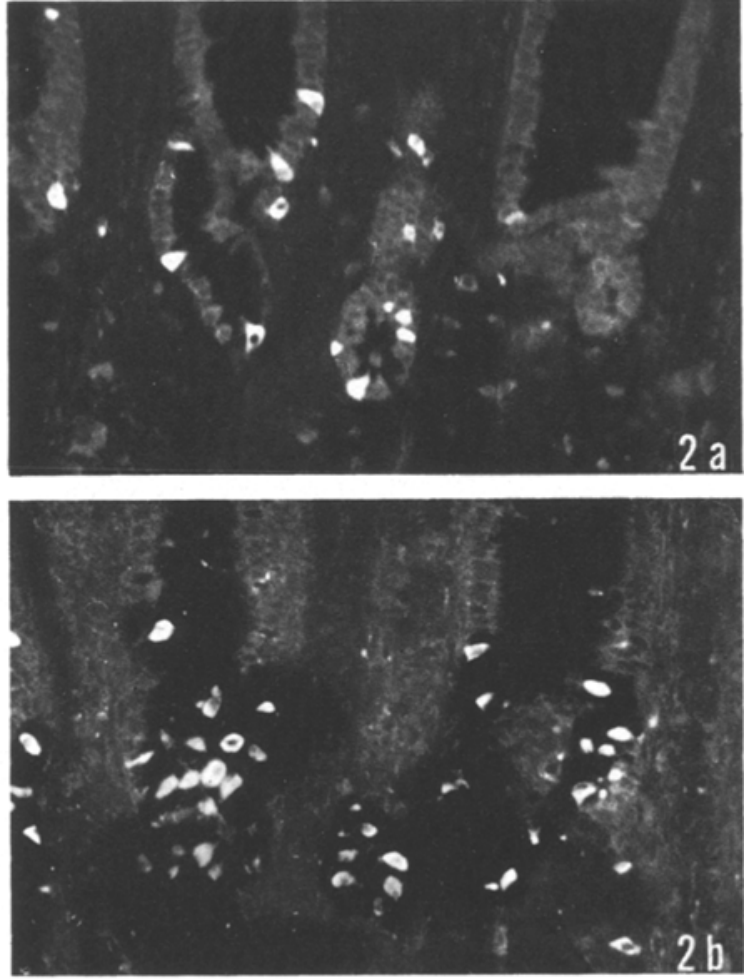

Fig. 2. Two serial sections from dog antral mucosa. a) Incubation with anti-somatostatin serum. Several fluorescent cells are scattered in the glandular epithelium. b) Incubation with anti-gastrin serum. Fluorescent cells are more numerous. Note that all the cells exhibiting fluorescence in a) are different from the fluorescent cells in b)

synthetic gastrin (control b). Conversely, gastrin immuno-fluorescence was abolished after adsorption of the specific serum with synthetic gastrin (control c), but remained unaffected by adsorption with synthetic somatostatin (control d). Incubation of the sections with normal rabbit serum followed by FITC, or with FITC alone failed to produce any fluorescence (controls e and f). Finally, by studying serial sections, it was shown that cells with anti-somatostatin immunofluorescence were different from those with antigastrin immuno-fluorescence (Fig. 2a, b).

\section{Discussion}

The present results suggest that somatostatin is present in the GI tract of the dog. This statement is made with the reservation that immuno-fluorescence does not allow a determination of the precise structure of the detected antigen, and hence cannot completely exclude a possible cross-reaction with a closely related polypeptide. The presence of somatostatin-containing cells in the GI tract raises the question of their functio- 
nal significance. The detection of somatostatin-containing cells in pancreatic islets [20,21], and the demonstration of an inhibitory effect of somatostatin upon insulin and glucagon release [2-14] had led to the suggestion that locally produced somatostatin might control pancreatic endocrine function $[20,21]$. Since somatostatin inhibits gastrin secretion [16] and since somatostatin-containing cells lie in close neighbourhood to gastrin-producing cells, we suggest that locally produced somatostatin might also control gastrin secretion. More generally, in view of the influence of somatostatin on the release of various secretion products [2-16, 25-28], and of the multifocal distribution of somatostatin-containing cells, we suggest that somatostatin modulates secretion in a large number of organs, yet affecting selectively those secretory cells neighbouring its site of release. This would then provide an explanation for our finding that somatostatin-containing cells are distributed throughout the entire GI tract, where they could influence directly a variety of secretory cells $[14,16,25-28]$. The challenge that now confronts us is to characterize at the ultrastructural level the cell type corresponding to the somatostatin-containing cell. The pancreatic and gastro-intestinal D-cell (for review see 29) is the best candidate for being the somatostatin-containing cell. In this respect we have recently found that the pancreas of the pigeon, which is particularly rich in Dcells $\left(\mathrm{A}_{1}\right.$-cells $)[30]$ has particularly numerous antisomatostatin immuno-fluorescent cells [3].

Acknowledgments. We are grateful to Dr. J. Rivier and Dr. R. Guillemin for their generous gift of cyclic somatostatin. We are also very obliged to Dr. W. Gepts for providing synthetic gastrin and anti-gastrin serum. We wish to acknowledge the excellent technical assistance of Mrs Angelica Irribarra and Mr Max Baumann. This work was supported by grants No 3.808-1.72, 3.553.75, from the fonds National Suisse de la Recherche Scientifique, and by grant No 74-4-445-35 from the I.N.S.E.R.M. (France).

\section{References}

1. Brazeau, P., Vale, W., Burgus, R., Ling, N., Butcher, M., Rivier, J., Guillemin, R.: Hypothalamic polypeptide that inhibits the secretion of immunoreactive pituitary growth hormone. Science 179, 77-79 (1973)

2. Alberti, K. G. M.M., Christensen, S. E., Iversen, J., Seyer-Hansen, K., Christensen, N.J., Hensen, A.P., Lundbaeck, K., Orskov, H.: Inhibition of insulin secretion by somatostatin. Lancet 1973 II, 1299-1301

3. Koerker, D.J., Ruch, W., Chideckel, E., Palmer, J., Goodner, C. J., Ensinck, J., Gale, C. C.: Somatostatin: hypothalamic inhibitor of the endocrine pancreas. Science 184, 482-484 (1974)

4. DeVane, G. W., Siler, T.M., Yen, S. S. C.: Acute suppression of insulin and glucose levels by synthetic somatostatin in normal human subjects. J. clin. Endocr. 38, 913-915 (1974)

5. Yen, S. S.C., Siler, T.M., DeVane, G.W.: Effect of somatosta- tin in patients with acromegaly. Suppression of growth hormone, prolactin, insulin and glucose levels. New Engl. J. Med. 290, 935-938 (1974)

6. Mortimer, C.H., Carr, D., Lind, T., Bloom, S.R., Mallinson, C.N., Schally, A.V., Turnbridge, W.G.M., Yeomans, L., Coy, D.H., Kastin, A., Besser, G.M., Hall, R.: Effects of growthhormone release-inhibiting hormone on circulating glucagon, insulin, and growth hormone in normal, diabetic, acromegalic, and hypo-pituitary patients. Lancet 1974 I, 697-701

7. Chen, M., Smith, P.H., Woods, S.C., Johnson, D. G., Porte, D., Jr.: Direct inhibitory effects of somatostatin on dog pancreatic endocrine function in vivo. Diabetes 23, 356 (1974)

8. Sakurai, H., Unger, R.: Effects of somatostatin (SRIF) on insulin (I) and glucagon (G) and $\mathrm{I} / \mathrm{G}$ ratio in normal and diabetic dogs. Diabetes 23, 356 (1974)

9. Gerich, J., Lorenzi, M., Schneider, V., Kwan, C., Karam, J., Forsham, P.H.: Inhibition of pancreatic glucagon responses to arginine by somatostatin in normal subjects and in insulin dependent diabetics. Diabetes 23, 356 (1974)

10. Efendic, S., Luft, R., Grill, V.: Effect of somatostatin on glucose induced insulin release in isolated perfused rat pancreas and isolated rat pancreatic islets. FEBS Letters 42, 169-172 (1974)

11. Iversen, J.: Inhibition of pancreatic glucagon release by somatostatin in vitro. Scand. J. clin. Lab. Invest. 33, 125-129 (1974)

12. Curry, D. L., Bennett, L. L., Li, C.H.: Direct inhibition of insulin secretion by synthetic somatostatin. Biochem. biophys. Res. Commun. 58, 885-889 (1974)

13. Fujimoto, W.Y., Ensinck, J.W., Williams, R. H.: Somatostatin inhibits insulin and glucagon release by monolayer cell cultures of rat endocrine pancreas. Life Sci. 15, 1999-2004 (1974)

14. Dobbs, R., Sakurai, H., Sasaki, H., Faloona, G., Valverde, I., Baetens, D., Orci, L., Unger, R.: Glucagon: role in hyperglycemia of diabetes mellitus. Science 187, 544-547 (1975)

15. Siler, T.M., Yen, S. S. Y., Vale, W., Guillemin, R.: Inhibition by somatostatin on the release of TSH induced in man by thyrotropin-releasing factor. J. clin. Endocr. 38, 742-745 (1974)

16. Arnold, R., Köbberling, J., Track, N. S., Creutzfeldt, W.: Lowering of basal and stimulated serum immunoreactive gastrin and gastric secretion in patients with Zollinger-Ellison syndrome by somatostatin. Acta endocr. (Kbh.) suppl. 193, 75 (1975)

17. Hökfelt, T., Efendic, S., Johansson, O., Luft, R., Arimura, A.: Immunohistochemical localization of somatostatin (growth hormone release-inhibiting factor) in the guinea pig brain. Brain Res. 80, 165-169 (1974)

18. Pelletier, G., Larbie, F., Arimura, A., Schally, A. V.: Electron microscopic immunohistochemical localization of growth hormone-release inhibiting hormone (somatostatin) in the rat median eminence. Amer. J. Anat. 140, 445-450 (1974)

19. Dubois, M.P., Barry, J., Leonardelli, J.: Mise en évidence par immunofluorescence et répartition de la somatostatine (SRIF) dans l'éminence médiane des Vertébrés (mammifères, oiseaux, amphibiens, poissons). C.R. Acad. Sci. (Paris) 279, 1899-1902 (1974)

20. Luft, R., Efendic, S., Hökfelt, T., Johansson, O., Arimura, A.: Immunohistochemical evidence for the localization of somatostatin-like immunoreactivity in a cell population of the pancreatic islets. Medical Biology 52, 428-430 (1974)

21. Dubois, M.P.: Presence of immunoreactive somatostatin in discrete cells of the endocrine pancreas. Proc. nat. Acad. Sci. (Wash.) 70, 1340-1343 (1975)

22. Arimura, A., Sato, H., DuPont, A., Nishi, N., Schally, A.V.: Abundance of immunoreactive $\mathrm{GH}$-release inhibiting hormone in the stomach and the pancreas of rat. Fed. Proc. 34, 273 (1975) 
23. Lostra, F., van der Loo, W., Gepts, W.: Are gastrin-cells present in mammalian pancreatic islets? Diabetologia 10, 291-302 (1974)

24. Coons, A.H., Leduc, E.H., Connolly, J.M.: Studies on antibody production. I. A method for the histochemical demonstration of specific antibody and its application to a study of the hyperimmune rabbit. J. exp. Med. 102, 49-63 (1955)

25. Arnold, R., Creutzfeldt, W.: Hemmung der pentagastrininduzierten Säuresekretion des Magens beim Menschen durch Somatostatin. Dtsch. med. Wschr. 100, 1014-1016 (1975)

26. Barros D'Sa, A. A.J., Bloom, S.R., Baron, J. H.: Direct inhibition of gastric acid by growth-hormone release-inhibiting hormone in dogs. Lancet 1975 I, 886-887

27. Gomez-Pan, A., Reed, J.D., Albinus, M., Shaw, B., Hall, R.: Direct inhibition of gastric acid and pepsin secretion by growthhormone release-inhibiting hormone in cats. Lancet 1975 I, $888-890$

28. Creutzfèldt, W., Lankisch, P.G., Fölsch, U. R.: Hemmung der Sekretin- und Cholezystokinin-Pankreozymininduzierten Saftund Enzymsekretion des Pankreas und der Gallenblasenkontraktion beim Menschen durch Somatostatin. Dtsch. med. Wschr. 100, 1135-1138 (1975)
29. Fujita, T., Kobayashi, S.: The cells and hormones of the GEP endocrine system. In: Gastro-entero-pancreatic endocrine system (ed. T. Fujita), p. I. Stuttgart: Georg Thieme 1973

30. Roth, A.: Quantitative studies on the islets of Langerhans in the pigeon. Acta anat. (Basel) 69, 609-622 (1968)

31. Orci, L., Baetens, D., Rufener, C.: Evidence for the D-cell of the pancreas secreting somatostatin. Horm. Metab. Res. (in press)

32. Rufener, C., Amherdt, M., Dubois, M. P., Orci, L.: Ultrastructural immunocytochemical localization of somatostatin in Dcells of rat pancreatic monolayer culture. (submitted for publication)

\author{
Prof. L. Orci \\ Institut d' Histologie \\ et d' Embryologie \\ Univ. of Geneva \\ CH-1211 Geneva 4 \\ Switzerland
}

Note Added in Proof: By using a peroxidase labelling technique, we were recently able to identify ultrastructurally the somatostatin containing cell as the D-cell [32]. 